\title{
Consumer Preferences for Attributes of Interest of Honey Products
}

\author{
Christina Whidya Utami ${ }^{1} \&$ Steven Willyanto Harjono ${ }^{1}$ \\ ${ }^{1}$ Ciputra University, Surabaya, Indonesia \\ Correspondence: Christina Whidya Utami, Ciputra University, Surabaya, Indonesia.
}

Received: October 25, 2017

Accepted: November 3, 2017 Online Published: November 6, 2017

doi:10.20849/abr.v2i3.212

URL: https://doi.org/10.20849/abr.v2i3.212

\begin{abstract}
In selling products is the main thing to note, because of the appeal of consumer products will be a consideration in buying consumer goods. The appeal may be packaging, taste, price, volume or other product attributes. To cultivate the right product attributes required preferences of consumers. The purpose of this research is to know the attributes and combinations of product attributes Borneo Hive the most preferred by consumers. This research uses a quantitative approach with an analysis conjoint use SPSS program 20.0. The sample used in this study is 50 consumers ever buy Borneo Hive and product attributes are examined is the packaging, volume and price. The results of this study showed that the most preferred product attributes consumers Borneo Hive is the volume of packaging and prices followed. And for the most preferred attribute combination is the glass packaging with a volume of $500 \mathrm{ml}-350 \mathrm{ml}$ with the price of IDR 30,000-IDR.40,000.
\end{abstract}

Keywords: product attributes, analysis conjoint, consumer preferences

\section{Introduction}

The demand for honey in Indonesia has been increasing annually, aside from showing high demand it's also a new business opportunity in Indonesia. The tight competition amongst honey seller has a very big impact to the company Borneo Hive. Borneo Hive is a company that sells real honey products from Kalimantan, and was established in 2015. When it was first established Borneo Hive provided the products below: packaging: glass, volume $350 \mathrm{ml}$ and price IDR 75,000 . In order to compete in the tougher market in the following year Borneo Hive released additional products below: glass, $150 \mathrm{ml}$ priced at IDR 40,000 , glass $225 \mathrm{ml}$ priced at IDR 50,000 and glass $250 \mathrm{ml}$ priced at IDR 60,000 .

Adding products in year 2016 did not affect sales level significantly. This can be seen from the figure below:

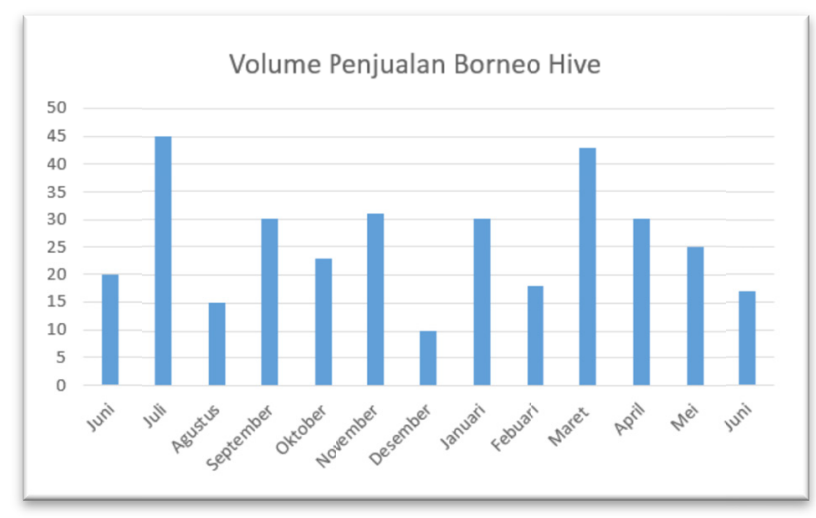

Figure 1

Sources: Internal, 2016

The variety of choices in product attribute is due to other competitors that resulted in consumers becoming more selective in choosing products. This is because of the different attributes from different companies have their own plus points and only the consumer can decide. Anis \& Lapian (2014) said that the product attributes are an important element that consumers consider important to base their purchase decision on. Based on the problem 
explained, Borneo Hive would like to study the product attribute that consumers based their decision on when deciding to purchase a certain product.

There were several existing studies that were used as the base for this study, the first study was a study done by Barge \& Bhola (2015). This study aimed to investigate consumer preference towards green cosmetic packaging for powder. Another study was a study done by Cahyanti and Najib (2016) that aimed to identify the characteristic of yoghurt drink consumers, analyzing consumer preference and consumer segmentation based on the level of importance in the attributes for yoghurt drink. The last study that was used as an actual source for this study was the study done by Barge, More dand Bhola (2015). The study aimed to investigate consumer preference in product attributes for soap, and the attribute variable used was the hydrogen saturation, price, material and type of scent.

\section{Theoretical Background}

\subsection{Consumer Preference}

According to Frank (2011:63), preference is a process of ranking all the products that can be consumed with the goal of obtaining a preference over a product or a service. From the result of the ranking process done by the customer, they can obtain the best products or services. Aside from that, according to Kotler in Sentosa and Poniman (2015) consumer preference is the feeling of like or dislike that an individual has towards a product (goods or services) that is consumed.

\subsection{Product Attribute}

Kotler and Amstrong (2014: 253) explained that the product attribute is the development of a product or a service that involves determining the benefit or use that the product yield and that use is communicated and conveyed. This became the base of choosing the three attributes consisting of price, packaging and volume/ content. The definition of product attribute according to Tjiptono in Resmawati (2013) is the product elements that the consumers deem important to be the base of decision making when making a purchase.

\subsection{Packaging}

Packaging is the activity of designing and producing a container or a wrapping for a product (Kotler and Amstrong, 2013: 368). A good packaging will attract consumer and encourage them to choose the product (Kotler and Keller, 2013: 368). According to Klimchuck \& Krasovec in Mawadah (2014) the function of packaging design is to communicate the difference in product visually. The size of the packaging is very tightly related with the way of handling after, in terms of storage, transportation or as an instrument to attract consumers' attention. (Boko 2013:12).

\subsection{Price}

According to Laksana in Trisnawan (2014), the price is the amount of money needed in order to exchange for the combination of product and services. Aside from that Barge \& Bhola (2015) defined price as the amount of money billed for a product or an amount exchanged by the consumer to gain the benefit of owning or using the product.

\subsection{Relationship between Product Attribute and Consumer Preference}

Product attribute became the base for consumers' preference to choose a certain product. According to Simamora in Sentoso and Poniman (2015), there are several steps that needs to be done before consumer form their preferences, the first is to assume that consumers view a product as a collection of attributes, different consumers have different perceptions about which attributes are relevant. Second, the level of importance for each attribute differs according to the needs and wants of each individual. Consumer has different emphasis on the attributes that they deem most important. Third, consumers develop an amount of trust about the position of each product in each attribute. Fourth, the level of satisfaction for each consumer about a product varies according to the difference in attribute. Fifth, consumer will act a certain way towards a brand differently through an evaluation process. Consumer preference focuses on the result of the best stimuli combination based on the level of usefulness obtained from the calculation, and the importance level of the attributes of the product (Prasidya, Deoranto, and Silalahi, 2015).

\section{Research Methodology}

The research approach was done using descriptive model and quantitative approach as well as conjoint analysis. 


\subsection{Population}

Population is the generalized area consisting of: object/subject that has a specific characteristic assigned by the researcher to study and draw conclusion from (Sugiyono, 2012: 90). Population used in this study is 100 consumers that purchased Borneo Hive's product.

\subsection{Research Sample}

Sample is a fraction of the population and has the characteristic of the population (Sugiyono 2012:120). Sampling in this study was done using the Slovin formula which was 50 consumers that purchased Borneo Hive's product.

\subsection{Data Collection Method}

The data collection techniques that can be used are interview, questionnaire, observation and all three (Sugiyono, 2014:137). The data collection technique used in this study was using primary data obtained from questionnaire. According to Sugiyono (2014: 142), questionnaire is an efficient data collection technique if the researcher knows with whom the variable will be measured against and what can be expected from the respondent. The questionnaire was distributed to consumers who purchased Borneo Hive's products.

\subsection{Data Analysis Method}

The analysis used in this study was conjoint analysis. According to Kotler and Keller (2013:221), conjoint analysis is a method that originated from the usefulness value disclosed by the consumer based on the level of usefulness of a product's attribute. Conjoint analysis is a non-parametric analysis, and non-parametric analysis is a statistic that does not need assumptions about the shape of the distribution or is randomly distributed, therefore it does not need assumption for population that will be tested.

\section{Result and Discussion}

\subsection{Results}

The data processing in this study was done with the help of SPSS version 20.0, and the analysis used in this study was conjoint analysis to investigate consumer preference in choosing Borneo Hive's products. The attributes used in this study was packaging, volume and price. Below are the variables for each of the selected attributes:

Table 1. Product attribute

\begin{tabular}{ll}
\hline Product Atribute & Variable \\
\hline Packaging & Plastic \\
\hline Volume & Glass \\
\hline & $50 \mathrm{~m}-150 \mathrm{ml}$ \\
\hline & $150 \mathrm{ml}-250 \mathrm{ml}$ \\
\hline Price & $350 \mathrm{ml}-500 \mathrm{ml}$ \\
\hline & IDR 30.000- IDR 40.000 \\
\hline & IDR 40.000 -IDR 50.000 \\
\hline
\end{tabular}

Source: Internal, 2016

Therefore, there were 9 stimuli combinations formed as listed below: 
Table 2. Stimuli combination results

\begin{tabular}{|c|c|c|c|c|c|}
\hline & Kemasan & Volume & Harga & STATUS_ & CARD_ \\
\hline 1 & Plastik & $350 \mathrm{ml}-500 \mathrm{ml}$ & Rp. 30.000 - Rp. 40.000 & Design & 1 \\
\hline 2 & Plastik & $150 \mathrm{ml}-250 \mathrm{ml}$ & Rp. 50.000 - Rp. 60.000 & Design & 2 \\
\hline 3 & Plastik & $50 \mathrm{ml}-150 \mathrm{ml}$ & Rp. 50.000 - Rp. 60.000 & Design & 3 \\
\hline 4 & Plastik & $350 \mathrm{ml}-500 \mathrm{ml}$ & Rp. 40.000 - Rp. 50.000 & Design & 4 \\
\hline 5 & Kaca & $350 \mathrm{ml}-500 \mathrm{ml}$ & Rp. 50.000 - Rp. 60.000 & Design & 5 \\
\hline 6 & Plastik & $150 \mathrm{ml}-250 \mathrm{ml}$ & Rp. 40.000 - Rp. 50.000 & Design & 6 \\
\hline 7 & Kaca & $150 \mathrm{ml}-250 \mathrm{ml}$ & Rp. 30.000 - Rp. 40.000 & Design & 7 \\
\hline 8 & Kaca & $50 \mathrm{ml}-150 \mathrm{ml}$ & Rp. 40.000 - Rp. 50.000 & Design & 8 \\
\hline 9 & Plastik & $50 \mathrm{ml}-150 \mathrm{ml}$ & Rp. 30.000 - Rp. 40.000 & Design & 9 \\
\hline
\end{tabular}

Stimuli combination formed in table 2 was used to determine the ranking in the questionnaire that was given to the 50 respondents. Respondents will then rank the combinations accordingly, 9 being the combination they like most and 1 being the combination they like least.

\subsection{Utility Value}

Table 3. Utility value all variants

\section{Utilities}

\begin{tabular}{|c|c|c|c|}
\hline & & Utility Estimate & Std. Error \\
\hline \multirow{2}{*}{ Packagin } & Plastic & $-1,255$ & ,236 \\
\hline & Glass & 1,255 & ,236 \\
\hline \multirow{3}{*}{ Volume } & $50 \mathrm{ml}-150 \mathrm{ml}$ & $-2,140$ & ,315 \\
\hline & $150 \mathrm{ml}-250 \mathrm{ml}$ &, 000 & ,315 \\
\hline & $350 \mathrm{ml}-500 \mathrm{ml}$ & 2,140 & ,315 \\
\hline \multirow{3}{*}{ Price } & IDR. 30.000 - IDR. 40.000 &, 660 & ,315 \\
\hline & IDR. 40.000 - IDR. 50.000 &,- 260 & ,315 \\
\hline & IDR. 50.000 - IDR. 60.000 &,- 400 &, 315 \\
\hline (Constant) & & 5,418 & ,236 \\
\hline
\end{tabular}

Source: SPSS, 2016

According to the utility value in Table 3, against packaging attribute, the attribute plastic packaging has a negative value (-1.255) and is therefore disliked by the respondent. On the contrary, glass packaging attribute is liked by respondents because of the positive value (1.255)

According to utility value in table 3 against volume attribute, the volume attribute $50 \mathrm{ml}-150 \mathrm{ml}(2,140)$ is not favored by respondents, whereas volume attribute volume $150 \mathrm{ml}-250 \mathrm{ml}(0.000)$ is favored by consumers and the volume attribute most favored by consumers is $350 \mathrm{ml}-500 \mathrm{ml}(2.140)$.

According to the utility value in table 3 against price attribute, price attribute IDR 30,000 - IDR 40,000 (0.660) is favored by respondents, respondents does not really favor the price attribute of IDR 40,000 - IDR 50,000 $(-0.260)$ and price attribute of IDR 50,000 - IDR 60,000 (-0.400) based on the negative values.

Therefore, in conclusion, the best combination of attribute based on the utility value is a Borneo Hive product with glass packaging and volume of 350ml-500ml priced at IDR 30,000 - IDR 40,000. 


\subsection{Value of Importance}

Table 4. Value of important

\begin{tabular}{ll}
\hline Packaging & 27,672 \\
\hline Volume & 48,887 \\
\hline Price & 23,441 \\
\hline
\end{tabular}

Source: SPSS, 2016

Table 4 displays the level of importance for each attribute in this study, the most important being volume (48.887\%), followed by packaging $(27.672 \%)$ and the last is price $(23.441 \%)$.

\subsection{Predictive Accuracy}

Predictive Accuracy was done with the aim to evaluate the correlation between the estimated value and the actual value measured by the accuracy value in terms of Pearson's R and Kendall's tau.

Table 5. Predictive accuracy

\begin{tabular}{lll}
\hline & Value & Sig. \\
\hline Pearson's R &, 984 &, 000 \\
Kendall's tau &, 944 &, 000 \\
\hline
\end{tabular}

Source: SPSS, 2016

According to table 5 the correlation value of Pearson's R is 0.984 and Kendall's tau is 0.944 . This indicated a very high correlation value since it's more than 0.05 and is coupled with significance value of less than 0.05 .

Table 6 displayed the product attribute that is most favored and that is volume product attribute with the value $48.885 \%$ followed by packaging $27.672 \%$ and lastly price $23.441 \%$. For the attribute combination most favored is the product with glass packaging with volume $350 \mathrm{ml}-500 \mathrm{ml}$ and priced at Rp. $30.000-\mathrm{Rp} .40 .000$

Table 6. Utility value all varians

\section{Utilities}

\begin{tabular}{llll}
\hline & & Utility Estimate & Std. Error \\
\hline \multirow{2}{*}{ Packaging } & Plastic & $-1,255$ &, 236 \\
& Glass & 1,255 &, 236 \\
\multirow{4}{*}{ Volume } & $50 \mathrm{ml}-150 \mathrm{ml}$ & $-2,140$ &, 315 \\
& $150 \mathrm{ml}-250 \mathrm{ml}$ &, 000 &, 315 \\
& $350 \mathrm{ml}-500 \mathrm{ml}$ & 2,140 &, 315 \\
\multirow{4}{*}{ Price } & IDR 30.000 - IDR. 40.000 &, 660 &, 315 \\
& IDR. $40.000-$ IDR. 50.000 &,- 260 &, 315 \\
& IDR. $50.000-$ IDR 60.000 &,- 400 &, 315 \\
\hline
\end{tabular}




\section{Discussion}

\subsection{Packaging}

Table 4 indicated that the packaging variable attribute for honey product that is most favored is glass packaging with utility value of 1.255 . This indicated that respondents favor glass packaging more than plastic packaging. This is correlated with the occupation of the respondent with majority being undergraduate students with higher education that shows awareness to green marketing by selecting glass packaging. Glass packaging can be recycled and does not pollute the environment and adds to the aesthetic of the product.

\subsection{Volume}

Table 4 indicated that the volume attribute most favored is $350 \mathrm{ml}-500 \mathrm{ml}$ because it has the utility value of 2.140 . This indicated that the respondent prefer volume product attribute of $350 \mathrm{ml}-500 \mathrm{ml}$ compared to $50 \mathrm{ml}-150 \mathrm{ml}$ and $150 \mathrm{ml}-250 \mathrm{ml}$. The fact that respondents prefer $350 \mathrm{ml}-500 \mathrm{ml}$ as the volume attribute indicated that respondents purchase and consume honey product on a daily basis due to its large quantity.

\subsection{Price}

Table 4 indicated that the price attribute most favored is IDR 30,000 - IDR 40,000 because it has the utility value of 0,660 . This indicated that the respondents prefer the price product attribute IDR 30,000 - IDR 40,000 compared to IDR 40,000 - IDR 50,000 and IDR 50,000 - IDR 60,000. The fact that respondents chose the cheapest price range IDR 30,000 - IDR 40,000 indicated that consumers or respondents of Borneo Hive is sensitive towards price, they seem to think that honey is not a primary good but rather a secondary good and therefore will think to select a secondary good with the cheapest price.

\section{Conclusion and Suggestion}

\subsection{Conclusion}

According to the study result done by conjoint analysis that considered three attributes which were packaging, volume and price the findings indicated that the product attribute that the respondents feel was most important is volume (48.887\%), followed by packaging $(27.672 \%)$ and lastly price $(23.441 \%)$ and the combination of product attribute most favored by consumers is Borneo Hive product with glass packaging and volume of $350 \mathrm{ml}-500 \mathrm{ml}$ priced at IDR 30,000 - IDR 40,000.

\subsection{Suggestion}

\subsubsection{Suggestion for the Company}

a) The results from this research will hopefully be useful for Borneo Hive as a base to develop their products. This is due to the fact that the research result was obtained from the respondents which are Borneo Hive's consumers.

b) The results from this research will hopefully help Borneo Hive to improve upon the positive factors that the company already possess and to change the negative factors into a positive one for the company.

c) The results from this research might change overtime due to the development of consumers' demands, therefore company is expected to conduct survey regularly to be able to adjust to the changes in market demand.

d) Research results is expected to be used according to the adjustments to the real market conditions.

\subsubsection{Suggestion for Further Studies}

a) Further studies should consider the product attribute that is most important for the object of the research before conducting conjoint analysis..

b) Further studies should not include too many product attributes and level so as to not make it difficult for respondents to respond to the questionnaire and therefore the respondents may not respond as optimally as expected.

c) Further studies is expected to present pictures and more comprehensive explanation to respondents when conducting the survey.

\subsection{Research Limitation}

The limitation in this study is the distance and time to meet the respondents. The respondents chosen were consumers that has previously bought Borneo Hive product. Because the respondents are spread all over 
Surabaya, the researcher needed time to travel the distance in order to collect the data from the respondents individually.

\section{References}

Anis, H. B., \& Lapian, S. L. H. V. (2014). Atribut Produk Dan Bauran Promosi Pengaruhnya Terhadap Keputusan Pembelian Sepeda Motor Yamaha Mio. JURNAL RISET EKONOMI, MANAJEMEN, BISNIS DAN AKUNTANSI, 2(1).

Barge, D. S., More, D. K., \& Bhola, S. S. (2015). A Research Paper-Preferences of Samples Towards Soap Attributes: Conjoint Analysis. SMS Varanasi, 11(2).

Bhola,S.S, More, K.D, \& Barge, S.D. (2015). A Research Paper-Preferences Of Samples Towards Soap Attributes : Conjoint Analysis.

Boko, M. D. W. R., Bab, I., \& Situasi, A. A. (2013). Penerapan Cara Produksi Pangan Yang Baik Dan Penggunaan Teknologi Pengemasan Untuk Meningkatkan Mutu Produk.

Cahyanti, T., \& Najib, M. (2016). Analisis Preferensi Konsumen terhadap Atribut Yogurt Drink (Studi Kasus Kota Bogor Jawa Barat). Jurnal Aplikasi Manajemen, 14(1), 176-183. https://doi.org/10.18202/jam23026332.14.1.19

Frank, Robert H. (2011). Microeconomics and Behavior (8th ed.). Mc.Graw. Hill International Edition.

Kotler, P., \& Amstrong, G. (2014). Principles of Marketing (15th ed.). New Jersey: Prentice Hall.

Kotler, P., \& Keller, K. L. (2013). Marketing Management (14th ed.). England: Pearson Education Limited 2013.Kualitatif Dan R\&D. Bandung: Alfabeta.

Mawadah, I. (2014). Pengaruh Kemasan Terhadap Minat Beli Konsumen. Studi Empiris Pada Produk Mie Sedap Cup Di Kab. Ngawi (Doctoral dissertation, Universitas Muhammadiyah Surakarta).

Prasidya, G., Deoranto, P., \& Silalahi, R. L. R. Analisis Preferensi Konsumen Terhadap Produk Bakpia Pia Djogdja Dengan Metode Konjoin (Analysis of Consumer Preference Towards Bakpia Pia Djogdja Products With Conjoint Methods.) Studi Kasus Pada Perusahaan Bakpia Pia Djogdja, Yogyakarta

Resmawati, T. (2013). Analisis Preferensi Konsumen Terhadap Produk Susu Berbasis (Analisis Conjoint Menggunakan Metode Presentasi Pairwise-Comparison). Studi Kasus Di Beberapa Smp Kecamatan Banyumanik Kota Semarang (Doctoral Dissertation, Universitas Diponegoro).

Sentoso, A. C., \& Poniman, A. S. (2015). Analisa Faktor Yang Menjadi Preferensi Konsumen Dalam Memilih Coffee Shop Di Surabaya. Jurnal Hospitality Dan Manajemen Jasa, 1(1), 1-11.

Sugiyono. (2014). Metode Penelitian Pendidikan Pendekatan Kuantitatif.

Trisnawan, A. D. (2014). Pengaruh Kualitas Produk, Harga, Promosi dan Distribusi Terhadap Loyalitas Konsumen Handphone Samsung Di Semarang. Skripsi, Fakultas Ekonomi Dan Bisnis.

\section{Copyrights}

Copyright for this article is retained by the author(s), with first publication rights granted to the journal.

This is an open-access article distributed under the terms and conditions of the Creative Commons Attribution license (http://creativecommons.org/licenses/by/4.0/). 